\title{
SIMVASTATIN ASSAY AND DISSOLUTION STUDIES BY FEASIBLE RP-HPLC IN TABLETS
}

Flávia Dias Marques-Marinho*, Amanda Leão dos Santos and Cristina Duarte Vianna-Soares

Departamento de Produtos Farmacêuticos, Faculdade de Farmácia, Universidade Federal de Minas Gerais, Av. Pres. Antônio Carlos, 6627, 31270-901 Belo Horizonte - MG, Brasil

Ilka Afonso Reis

Departamento de Estatística, Instituto de Ciências Exatas, Universidade Federal de Minas Gerais, Av. Pres. Antônio Carlos, 6627, 31270-901 Belo Horizonte - MG, Brasil

José Carlos da Costa Zanon

Clínica Ouro Cordis, Hospital Santa Casa, R. José Moringa, 620, 35400-000 Ouro Preto - MG, Brasil

Angélica Alves Lima

Departamento de Análises Clínicas, Escola de Farmácia, Universidade Federal de Ouro Preto, R. Costa Sena, 171, 35400-000

Ouro Preto - MG, Brasil

Recebido em 19/9/11; aceito em 10/12/11; publicado na web em 23/3/12

\begin{abstract}
Commonly used HPLC acetonitrile solvent has been through a worldwide shortage with a cost increase in 2008 and 2009. In order to get around this situation, a method by RP-HPLC employing methanol and aqueous acid mobile phase was developed and validated to evaluate simvastatin. The quality control assay and dissolution studies of this lipid-lowering drug were performed in diluents methanol and $0.01 \mathrm{M}$ phosphate buffer with $0.5 \% \mathrm{SDS}, \mathrm{pH} 7$, respectively. Dissolution test aliquots did not go through sample treatment, as described in USP SIM tablets monograph by ultraviolet spectrophotometry. The proposed method is fast, simple, feasible and robust.
\end{abstract}

Keywords: Simvastatin tablets; dissolution studies; RP-HPLC.

\section{INTRODUCTION}

Simvastatin (SIM, Figure 1a), 2,2-dimethyl-, 1,2,3,7,8,8ahexahydro-3,7-dimethyl-8-[2-(tetrahydro-4-hydroxy-6-oxo$2 H$-pyran-2-yl)ethyl]-1-naphthalenyl ester [ $1 S$-[1a,3a,7b,8b $\left.\left.\left(2 S^{*}, 4 S^{*}\right), 8 \mathrm{ab}\right]\right]$ butanoic acid is one of the most used statins as lipid-lowering agents, for the treatment of hypercholesterolemia. ${ }^{1,2}$ It reduces the morbidity and mortality associated with chronic heart disease. ${ }^{3}$ SIM is commercially available as tablets. Similarly to lovastatin (LOV, Figure 1b) SIM is administered in lactone form as a pro-drug, which is enzymatically hydrolyzed in vivo to active $\beta$-hydroxy acid form (Figure 1c), particularly in liver. The active form competitively inhibits 3-hydroxyl-3-methylglutarylcoenzyme A (HMG-CoA) reductase, which converts HMG-CoA to mevalonate, a rate-limiting step in cholesterol biosynthesis. ${ }^{4-6}$

SIM is semi-synthetically produced from LOV, which is a natural fermentation product of Aspergillus terreus. Hence, LOV can be found in SIM raw material as impurity. ${ }^{2,7-9}$ SIM quantitation in bulk or finished products samples has been reported using ultraviolet spectrophotometry and liquid chromatography (LC-UV/DAD). ${ }^{10-19}$ LC ion-par coupled to UV detector and visible spectrometric method have also been reported. ${ }^{20,21}$ Furthermore, LC-MS/MS was employed to identify SIM impurities or degradation products in bulk drug or tablets dosage form. ${ }^{22,23}$ UV spectrometry, LC-UV and LC-MS have been reported to quantify SIM associated with other drugs such as ezetimibe, gemfibrozile or in multi-drugs formulation. ${ }^{24-27}$ A micellar electrokinetic chromatographic (MEKC) method has been employed to quantify SIM and LOV in tablets. ${ }^{28}$ Several other studies, not here considered because of its focus on SIM quantitation in biological samples describe LC coupled with UV or fluorescence detectors. LC is the most commonly reported method due to its feasibility to

*e-mail: flaviadmar@hotmail.com

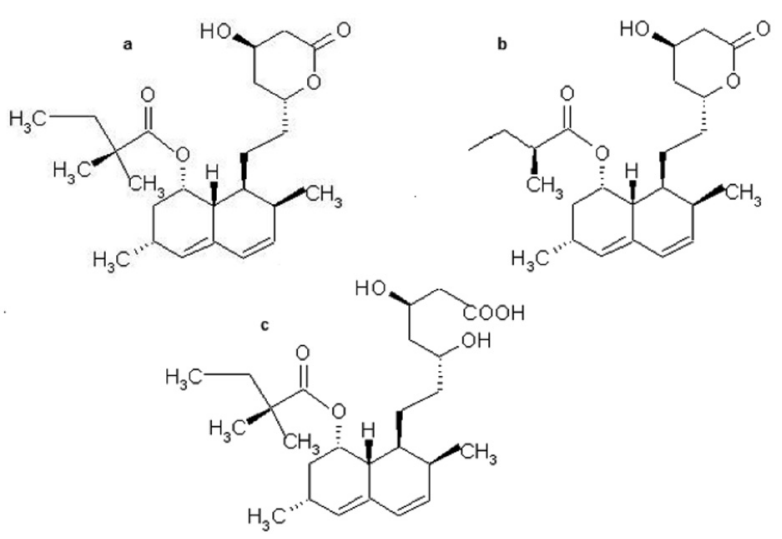

Figure 1. Chemical structure of (a, SIM) simvastatin, (b, LOV) lovastatin and (c) SIM $\beta$-hydroxy acid

couple with several detection techniques. Acetonitrile (ACN) widely used in combination with buffer solution in mobile phases, mainly in SIM official monographs of solid dosage forms. ${ }^{2,11,12,14,15,18,20,22,23,25-27,29}$ Methanol in a binary mobile phase has been reported for SIM determination in nanoparticles (specific pharmaceutical dosage form) in the concentration range $20-80 \mu \mathrm{g} \mathrm{mL}^{-1}$. ACN worldwide shortage has reached a very high cost in the market between years 2008 and 2009. ${ }^{30}$ In order to get around this situation, an alternative lower cost methanolic mobile phase, not only to assay SIM, but also, to determine SIM in dissolution studies was applied for tablets routine analysis.

\section{EXPERIMENTAL}

\section{Chemicals and reagents}

United States Pharmacopeia (USP) simvastatin reference standard 
(RS, lot I0D382, 99.4\% purity, Rockville, MD, USA), lovastatin pharmaceutical grade gently donated by Pharma Nostra (lot 07061205A, $99.9 \%$ purity, Rio de Janeiro, RJ, Brazil) and locally purchased Zocor ${ }^{\circledR}$ 20 mg tablets samples (Merck Sharp Dohme, Campinas, SP, Brazil) were used. Methanol HPLC grade (Tedia, Fairfield, OH, USA), phosphoric acid $85 \%$ (Merck, Darmstadt, Germany), sodium dodecyl sulphate (Pharmacopéia Ativos Magistrais, Barueri, SP, Brazil), sodium hydroxide (J.T. Baker, Phillipsburg, NJ, USA) and monobasic sodium phosphate (Vetec, Rio de Janeiro, RJ, Brazil) were used as received. Distilled or ultrapurified water (Milli-Q-Plus, Millipore, Bedford, MA, USA) was used when necessary.

\section{Instrumentation}

The dissolution studies were performed in a DT80 (Erweka, Heusenstamm, Germany) dissolution system employing paddles (50 $\mathrm{rpm}$ ) and $0.5 \%$ sodium dodecylsulphate (SDS) in $0.01 \mathrm{M}$ monobasic sodium phosphate, final $\mathrm{pH} 7 \pm 0.05$ adjusted with $40 \% \mathrm{w} / \mathrm{v}$ sodium hydroxide $\left(900 \mathrm{~mL}, 37 \pm 0.5^{\circ} \mathrm{C}\right) .^{2,29}$ Withdrawn aliquots (with no media replacement) were filtered through a $0.45 \mu \mathrm{m}$ membrane and directly injected in the chromatograph.

Separations were performed in a HP1200 quaternary liquid chromatography system (Agilent, Palo Alto, CA, USA) with automatic injector fitted at $10 \mu \mathrm{L}$, ultraviolet diode array detector (UV/DAD) set at $\lambda 238 \mathrm{~nm}$, octylsilane column (C8 and C8e, $250 \times 4 \mathrm{~mm}, 5$ $\mu \mathrm{m})$ at $30{ }^{\circ} \mathrm{C}$ (Merck, Darmstadt, Germany) with data acquisition by internal software (Agilent ChemStation version Rev.B.02.01-SR1). Mobile phase consisted of methanol and 0.1\% phosphoric acid (80:20 $\mathrm{v} / \mathrm{v}$ ) at flow rate $1.5 \mathrm{~mL} \mathrm{~min}^{-1}$, with backpressure of circa 125 bar. All standard and sample solutions were filtered through a $0.45 \mu \mathrm{m}$ filter membrane (MiniSart RC15 Sartorius, Goettingen, Germany) before injection. Peak area was used for SIM quantitation.

\section{Standard solution preparation}

Stock solutions of SIM RS were accurately prepared in methanol $\left(200 \mu \mathrm{g} \mathrm{mL}^{-1}\right)$ and in the dissolution medium $\left(100 \mu \mathrm{g} \mathrm{mL}^{-1}\right)$. Diluted SIM standard solutions at $40 \mu \mathrm{g} \mathrm{mL}^{-1}$ were prepared in methanol for assay and at 2, 10, 18, 26, $34 \mu \mathrm{g} \mathrm{mL}^{-1}$ in the dissolution medium. All standard solutions were prepared in triplicate.

\section{Sample solution preparation}

Powdered tablets (20 units) equivalent to 5, 10, $20 \mathrm{mg}$ SIM were accurately weighed in a $50 \mathrm{~mL}$ volumetric flask (triplicate), added of $25 \mathrm{~mL}$ methanol and sonicated for $10 \mathrm{~min}$. Final volume was completed with the same diluent. The dispersions were filtered and aliquots of $10.0 \mathrm{~mL}$ were transferred to $50 \mathrm{~mL}$ flask volumetric to yield final concentrations $20,40,80 \mu \mathrm{g} \mathrm{mL}^{-1}$, respectively.

System suitability was verified by injections $(n=6)$ of SIM standard solution prepared in methanol $\left(40 \mu \mathrm{g} \mathrm{mL}^{-1}\right)$ and in dissolution medium $\left(22.2 \mu \mathrm{g} \mathrm{mL}^{-1}\right)$. The relative standard deviation (\%RSD) for SIM peak areas and retention times $\left(t_{R}\right)$ were accepted if less than 1.0 or $2.0 \%$ for assay or dissolution test, respectively. ${ }^{31,32}$ Chromatographic parameters as retention factor $(k)$, theoretical plates $(N)$, tailing factor $\left(T_{f}\right)$ and peak asymmetry $\left(A_{s}\right)$ were also evaluated.

\section{Method validation}

Calibration plots were built in two days in the mass range $0.04-0.80 \mu \mathrm{g}$ by injection of $1,5,10,15,20 \mu \mathrm{L}$ of SIM standard solution at $40 \mu \mathrm{g} \mathrm{mL}^{-1}$ in methanol and in the concentration range 2-34 $\mu \mathrm{g} \mathrm{mL}^{-1}$ for SIM solutions in dissolution medium by injection of $10 \mu \mathrm{L}$ of standard solutions at $2,10,18,26,34 \mu \mathrm{g} \mathrm{mL}^{-1}$. All injections were in triplicate. The calibration plots behavior, normality and homoscedasticity ( $\alpha 0.05)$ were verified by weighted least squares method using a linear regression model to determine the weights, ShapiroWilk and Levene tests, respectively. ${ }^{33}$ Residues greater or equal than 3.0 were removed by using studentized residuals model. Correlation coefficients, $r$, were calculated and results were considered significant if correspondent $\mathrm{p}$-value were less than 0.05 . All statistical analyses were performed using the R software (R Foundation for Statistical Computing, Vienna, Austria).

Limits of quantitation (LOQ) and detection (LOD) were determined in triplicate (for methanolic solutions only) by successive dilutions of the lowest calibration curve point. The concentration for which the maximum precision remained below the acceptance limit (RSD 2.0\%) was evaluated for LOQ. The minimum detectable area in the greatest dilution was considered for LOD..$^{31,34}$

The method selectivity was evaluated by comparison of SIM chromatogram standard solution in methanol $\left(40 \mu \mathrm{g} \mathrm{mL}^{-1}\right)$ with that of tablets excipients mixture (ascorbic acid, citric acid, hydroxypropylcellulose, butylated hydroxyanisole, hydroxypropylmethylcellulose, iron oxides, lactose, magnesium stearate, microcrystalline cellulose, starch, talc, titanium dioxide) in methanol. In dissolution medium, SIM standard solutions $\left(22.2 \mu \mathrm{g} \mathrm{mL}^{-1}\right)$ were compared with that obtained by addition of a placebo mass, equivalent to one average weight in three dissolution vessels, agitated at $150 \mathrm{rpm}$ for $30 \mathrm{~min} .{ }^{32}$

The intraday and inter-day precision for SIM tablets sample solutions $\left(20,40,80 \mu \mathrm{g} \mathrm{mL}^{-1}\right.$ in methanol, triplicate) was performed in three days. ${ }^{34,35}$ A different analyst performed the procedure at the third day. SIM standard solutions $\left(22.2 \mu \mathrm{g} \mathrm{mL}^{-1}\right.$ in dissolution medium, triplicate) were used to evaluate intra-day precision. Tablets dissolution test (30 min) inter-day precision was evaluated by different analysts in two days each. ${ }^{32}$ The results were calculated by the common plot equations.

The standard addition method was employed for accuracy studies. Sample tablet solution in methanol was prepared as in sample preparation, except that, it was at $15 \mu \mathrm{g} \mathrm{mL}^{-1}$ (37.5\% of working concentration). SIM standard solution aliquots were added, so that, 50, 100 and $200 \%$ of working concentration $\left(40 \mu \mathrm{g} \mathrm{mL}^{-1}\right)$ were obtained. The equation $\% \mathrm{R}=\left[\left(\mathrm{C}_{\mathrm{T}}-\mathrm{C}_{\mathrm{A}}\right) / \mathrm{C}_{\mathrm{S}}\right] \times 100$ was employed to determine SIM recovery, in which, $\mathrm{C}_{\mathrm{A}}$ is concentration in nonspiked solution, $\mathrm{C}_{\mathrm{T}}$ is total concentration in spiked solution and $\mathrm{C}_{\mathrm{S}}$ is concentration of standard solution. Accuracy in the dissolution medium $(900 \mathrm{~mL}$ per vessel) was obtained by addition of SIM RS in three different amounts $(2,20,30 \mathrm{mg})$ to a tablet placebo mixture, equivalent to one average weight. Each concentration was tested in triplicate..$^{32}$

Robustness was verified for SIM determination $\left(40 \mu \mathrm{g} \mathrm{mL}^{-1}\right.$ in methanol, $n=6$ ), by varying organic solvent $\pm 2.0 \%$, flow rate \pm 0.1 $\mathrm{mL} \mathrm{min}^{-1}$ and temperature $\pm 10^{\circ} \mathrm{C}$. Equivalent SIM standard solutions $(\mathrm{n}=3)$ were run in the same conditions. For SIM dissolution medium solutions $(\mathrm{n}=6)$, molarity $\pm 0.005 \mathrm{M}, \mathrm{pH} \pm 0.5$ and $\mathrm{C} 8 \mathrm{e}$ (endcapped) column were tested. SIM concentrations were calculated by the calibration plot equation. All data were evaluated by analysis of variance (ANOVA) in a significance level $\alpha 0.05$ using R statistical software.

In a short term stability study SIM RS methanolic solution $\left(40 \mu \mathrm{g} \mathrm{mL}^{-1}\right)$ was kept at room controlled temperature $\left(22-24^{\circ} \mathrm{C}\right)$ and was analyzed after $20 \mathrm{~h}$. Dissolution stability study was evaluated by the addition of $20 \mathrm{mg}$ SIM (one tablet) to dissolution medium ( $\left.37^{\circ} \mathrm{C}, 900 \mathrm{~mL}, 50 \mathrm{rpm}, 30 \mathrm{~min}\right)$. This solution $\left(22.2 \mu \mathrm{g} \mathrm{mL}^{-1}\right)$ was transferred to vials $(n=2)$, one kept at room temperature and the other at under refrigeration $\left(2-8^{\circ} \mathrm{C}\right)$. Vials were analyzed every hour during $7 \mathrm{~h}$ for comparison. A change less than $2.0 \%$ in the response was considered acceptable. ${ }^{34}$

Dissolution studies for SIM tablets $(n=6)$ release was performed in two days, using the previous described conditions until $45 \mathrm{~min}$ and, 
for additional $15 \mathrm{~min}$ at $150 \mathrm{rpm}$. Aliquots $(3 \mathrm{~mL})$ were withdrawn at the time intervals $3,5,8,10,12,15,30,45,60 \mathrm{~min}$, without medium replacement. Filtered aliquots were maintained at $2-8{ }^{\circ} \mathrm{C}$ previous to injection in the chromatograph. C8e (endcapped) column $(250 \mathrm{x}$ $4 \mathrm{~mm}, 5 \mu \mathrm{m}$ ) was used.

\section{RESULTS AND DISCUSSION}

Very few reports describe the use of $\mathrm{C} 8$ column to determine SIM in pharmaceutical samples. ${ }^{21-23,27}$ However, C8 has been chosen because separation shows a slightly lower peak retention time $\left(t_{R}\right)$ as fair as resolved as in a C18 column under the same conditions. Most reported studies, use isocratic or gradient elution of ternary or binary mobile phases containing acetonitrile $(\mathrm{ACN})$ as organic solvent, in a variable proportion from 60 to $85 \% \mathrm{v} / \mathrm{v}$, usually with buffer. ${ }^{12,17}$ Because there is a need to address method validation for SIM determination and dissolution studies, for which linear concentration ranges and diluents are usually different, a single feasible isocratic liquid chromatographic method was proposed. Due to ACN shortage and high cost in the market between years 2008 and 2009, an alternative less expensive solvent was desirable. ${ }^{30}$ Different options to reduce solvent cost are reported in the literature. ${ }^{36,37}$ Ribeiro et al. showed that low-cost ethanol can be a choice of mobile phase organic modifier for many RP-HPLC applications. However, its use is not worldwidely allowed, because of the control regulations in some countries, mainly in USA. ${ }^{36} \mathrm{~A}$ great effort has been done in order to substitute ACN by methanol, what does not require modifications in equipment nor in the column. ${ }^{37}$

A binary phase, methanol and water, has been reported for SIM quantitation in nanoparticles and in human plasma. ${ }^{19,38}$ No report has described the use of methanol binary phase in reverse column applied to SIM tablets.

Hence, solvent-strength nomograph for reverse-phase HPLC was used to estimate a correspondent methanol percentage necessary to substitute $\mathrm{ACN} .{ }^{31}$ Considering $72.5 \%$ as an average $\mathrm{ACN}$ percentage used in the reported mobile phases, a correspondent methanol percentage should be approximately $80 \%$. In this work, different ratios of methanol and $0.1 \%$ phosphoric acid $(75: 25,80: 20,85: 15,90: 10$ $\mathrm{v} / \mathrm{v}$ ) in isocratic elution were evaluated for SIM. The 80:20 and 85:15 mobile phase ratios yielded SIM $k$ values near 2.0 (3.54 and 1.79, respectively) and were used to evaluate the selectivity of SIM and LOV (SIM synthesis route precursor, $40 \mu \mathrm{g} \mathrm{mL}^{-1}$ of each, in methanol or $22.2 \mu \mathrm{g} \mathrm{mL}^{-1}$ in dissolution medium) at room temperature immediately after preparation and five days later. Superior chromatographic separation and resolution between SIM, LOV and their degradation products were observed for mobile phase 80:20 ratio than 85:15 one.

In the latter, nevertheless, peaks overlapping were observed for SIM and LOV degradation products in methanol (Figure 2) and for

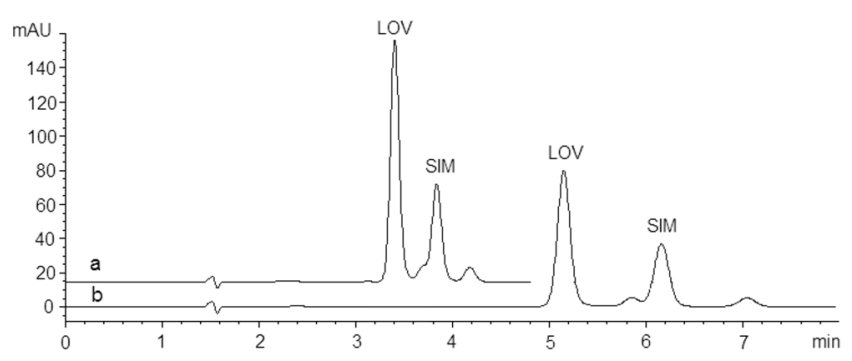

Figure 2. Chromatograms of SIM and LOV methanolic solution 5 days in room temperature after preparation, using methanol:0.1\% phosphoric acid (a) $85: 15 \mathrm{v} / \mathrm{v}$ and (b) 80:20 v/v as mobile phase, $1.5 \mathrm{~mL} \mathrm{~min} \mathrm{~m}^{-1}$, C8e $250 \times 4$ $\mathrm{mm}, 5 \mu \mathrm{m}, 30^{\circ} \mathrm{C}, 10 \mu \mathrm{L}, \lambda 238 \mathrm{~nm}$

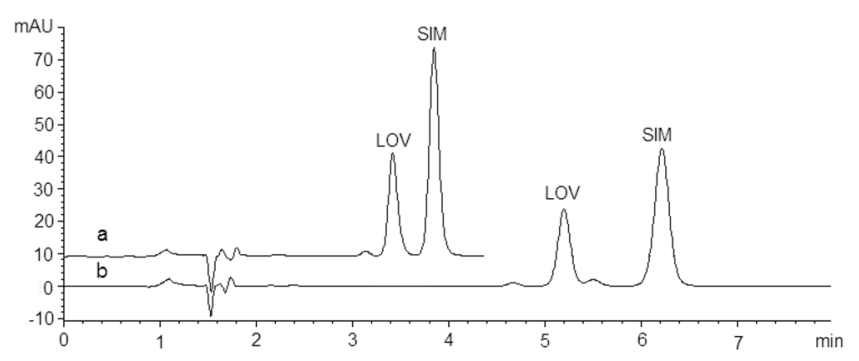

Figure 3. Chromatograms of SIM and LOV solution prepared in dissolution medium (0.5\% SDS in monobasic sodium phosphate, pH 7, $0.01 \mathrm{M}$ ) after 5 days in room temperature; using methanol:0.1\% phosphoric acid (a) 85:15 $v / v$ and $(b) 80: 20 v / v$ as mobile phase, $1.5 \mathrm{~mL} \mathrm{~min}^{-1}$, C8e $250 \times 4 \mathrm{~mm}, 5 \mu \mathrm{m}$, $30^{\circ} \mathrm{C}, 10 \mu L, \lambda 238 \mathrm{~nm}$

LOV and SIM degradation products in dissolution medium (Figure 3). Interestingly, it should be noted that the products eluted with greater $t_{R}$ than SIM and LOV in methanol. The presence of methanol may lead to lactone methanolysis and esterification, what is agreement with previous report. ${ }^{39}$ On the other hand, the more polar products eluted at lower $t_{R}$ in dissolution medium because of lactone hydrolyses to the corresponding acid form in aqueous solutions ( $\mathrm{pH} 7) .^{40}$ The products UV/DAD spectra (Figure 4) were identical to SIM and LOV original spectra in both diluents; revealing that the chromophore moiety is not affected by ring opening. ${ }^{41}$ For all these reasons, the 80:20 v/v ratio mobile phase $\left(1.5 \mathrm{~mL} \mathrm{~min}^{-1}, 30^{\circ} \mathrm{C}\right)$ was selected. Column temperature, set at $30^{\circ} \mathrm{C}$ helped reducing methanol:aqueous acid mobile phase viscosity, decreasing backpressure, therefore avoiding fluctuations. The backpressure was maintained around 125 bar.

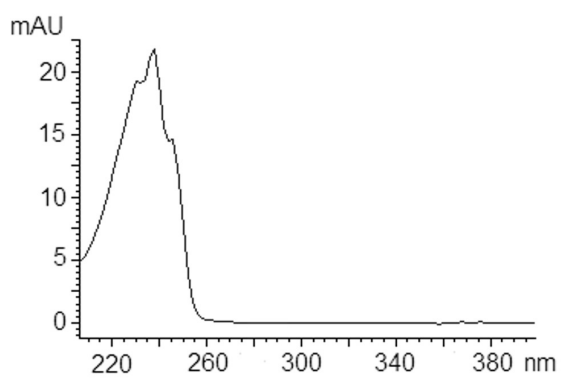

Figure 4. UV/DAD spectrum related to statin products chromatographic peaks in Figures 2 and 3

System suitability showed \%RSD values for peak area $(0.47$; $0.10)$ and $t_{R}(0.05 ; 0.02)$ less than $1.0 \%$ for methanol and dissolution medium solutions, respectively. The results also demonstrate the suitability of the system in terms of column efficiency greater than 2000 ( $N 5999 ; 6551)$, adequate peak shape less than $2.0\left(T_{f} 1.13 ; 1.15\right)$ or asymmetry less than $1.2\left(A_{s} 1.16 ; 1.19\right)$, appropriate SIM peak retention factor greater than $2.0(k 2.67 ; 4.43)$ for solutions in methanol and dissolution medium, respectively. ${ }^{31,34}$ No fluctuations in the baseline was observed during the runs. Hence, the proposed method showed system suitability for SIM determination in either diluent.

SIM calibration plots were built in both diluents. The simplest model that adequately described the concentration-response relationship was the weighted least squares method using a linear regression model (variances versus mean responses in each concentration) to determine the weights. ${ }^{42}$ The plots for SIM methanolic (Table 1) or dissolution medium (Table 2) solutions showed a linear behavior. No residues were removed for methanolic solutions plots, however, the common plot for dissolution medium solutions had two residues $(6.6 \%)$ removed, less than $22 \%$ of the data. ${ }^{43}$ 
Table 1. Results of adjusted regression model $(r>0.9999)^{a}$ for SIM determination in methanolic solutions $(0.04-0.80 \mu \mathrm{g}, \mathrm{n}=3)$ by HPLC

\begin{tabular}{llccc}
\hline SIM curve data & & Day 1 & Day 2 & Common curve \\
\hline Average area \pm SE & & $916.51 \pm 7.83$ & $922.84 \pm 3.80$ & $921.39 \pm 6.23$ \\
Regression equation & & $\mathrm{y}=2253.33 \mathrm{x}+1.55$ & $\mathrm{y}=2257.91 \mathrm{x}+2.93$ & $\mathrm{y}=2257.66 \mathrm{x}+1.88$ \\
\%RSD & 0.11 & 0.11 & 0.12 \\
p-value & Intercept & $0.01(0.17)^{\mathrm{c}}$ & $1.43 \times 10^{-3}(0.32)^{\mathrm{c}}$ & $6 \mathrm{x} 10^{-4}(0.21)^{\mathrm{c}}$ \\
& ShapiroWilk & 0.40 & 0.74 & 0.36 \\
& Levene & 0.97 & 0.92 & 0.59 \\
\hline
\end{tabular}

a: p-value $<2.0 \times 10^{-16}$; b: chromatographic conditions $\mathrm{C} 8(250 \times 4 \mathrm{~mm}, 5 \mu \mathrm{m}), 30^{\circ} \mathrm{C}$, methanol: $0.1 \%$ phosphoric acid $80: 20 \mathrm{v} / \mathrm{v}, 1.5 \mathrm{~mL} \mathrm{~min}{ }^{-1}, \lambda 238 \mathrm{~nm}$; c: intercept percentage relative to $100 \%$ analyte level that must be less than $2 \%$.

Table 2. Results of adjusted regression model $\left(\mathrm{r}^{2}>0.999\right)^{\mathrm{a}}$ for SIM determination $\left(2-34 \mu \mathrm{g} \mathrm{mL} \mathrm{m}^{-1}, \mathrm{n}=3\right)$ in dissolution medium ${ }^{\mathrm{b}}$ by HPLC

\begin{tabular}{llccc}
\hline SIM curve data & & Day 1 & Day 2 & Common curve \\
\hline Average area \pm SE & & $387.77 \pm 1.35$ & $386.31 \pm 1.41$ & $387.21 \pm 1.66$ \\
Regression equation & & $\mathrm{y}=21.545 \mathrm{x}-0.140$ & $\mathrm{y}=21.453 \mathrm{x}-0.178$ & $\mathrm{y}=21.526 \mathrm{x}-0.107$ \\
\%RSD & & 0.29 & 0.17 & 0.29 \\
p-value & Intercept & 0.97 & 0.60 & 0.68 \\
& ShapiroWilk & 0.44 & 0.87 & 0.13 \\
& Levene & 0.92 & 0.86 & 0.86 \\
\hline
\end{tabular}

a: p-value $<2.0 \times 10^{-16}$; b: $0.5 \%$ SDS in monobasic sodium phosphate $(\mathrm{pH} 7,0.01 \mathrm{M})$; c: conditions as in Table 1.

Plots in methanol, as well as, in dissolution medium showed no significant parallelism deviation by ANOVA ( $\mathrm{p}$-value $>0.05$ ). Common regression plots were significant ( $\mathrm{p}$-value $<0.05$ ), correlation coefficients ( $r$ ) were above 0.999 and determination coefficients $\left(\mathrm{r}^{2}\right)$ were greater or equal $0.98 .^{32,44}$ The regression RSD values were less than $1.0 \%$. Intercept was not statistically different from zero for dissolution medium solutions ( $\mathrm{p}$-value $>0.05$ ) and percentage of the intercept relative to $100 \%$ analyte level was less than $2.0 \%$ for methanolic solutions. ${ }^{32,44}$ For both diluents, data analyses followed adequate normality and homoscedasticity ( $\mathrm{p}$-value $>0.05$ ).

RSD value found (1.2\%) for LOQ was lower than $2.0 \%$ for SIM methanolic solutions. ${ }^{34}$

The method selectivity is demonstrated in Figures 5 and 6 for methanolic and dissolution medium solutions, respectively. Tablet (b) placebo constituents did not exhibit interfering peaks over (a) SIM RS retention time. Tablet (c) placebo added of SIM RS methanolic solutions also did not interfere in (a) SIM RS retention time.

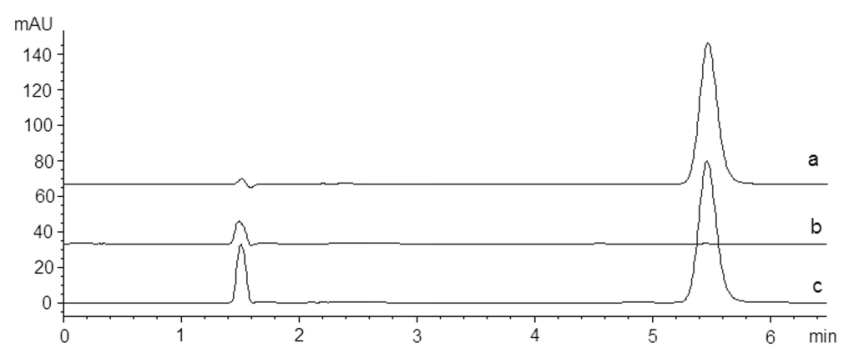

Figure 5. Chromatograms of (a) simvastatin reference standard, (b) tablets placebo and (c) tablets placebo added of SIM RS in methanol. Chromatographic conditions: $\mathrm{C} 8(250 \times 4 \mathrm{~mm}, 5 \mu \mathrm{m}) 30^{\circ} \mathrm{C}$, methanol: $0.1 \%$ phosphoric

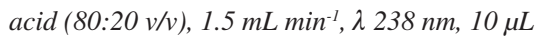

The RSD values for intraday $(1.86,1.34 \%)$ and inter-day $(2.02$, $1.47 \%$ ) precision were equal or lower than the acceptance limits for methanolic and dissolution medium solutions, as shown in Table 3 and Table 4 , respectively. ${ }^{32,35}$

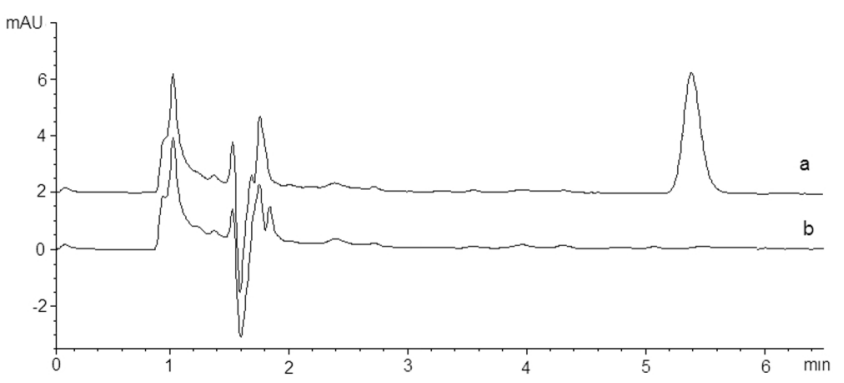

Figure 6. Chromatograms of (a) simvastatin reference standard and (b) tablets placebo in dissolution medium. Chromatographic conditions: as in Figure 5. Dissolution conditions: $0.5 \%$ SDS in monobasic sodium phosphate ( $p H 7$, $0.01 \mathrm{M}$ ), $900 \mathrm{~mL}, 37^{\circ} \mathrm{C}$, paddles, $150 \mathrm{rpm}, 30 \mathrm{~min}$

Accuracy found values ranged from 99.5 to $100.5 \%$ for SIM methanolic solutions, attesting the usual range of acceptance for pharmaceutical products (98.0 to $102.0 \%) .{ }^{35}$ Dissolution medium solutions found values (99.1 to $100.4 \%$ ) ranged between 95.0 and $105.0 \%$ for tablets placebo added of 2.0, 20.0 and $30.0 \mathrm{mg}$ of SIM, in accordance with the USP34 criteria. ${ }^{32}$ These results attest the accuracy.

Robustness statistical analysis (Table 5) showed no significant difference ( $\alpha 0.05$ ) between standardized (nominal) analytical conditions and deliberate variations. The method using HPLC can be applied in a temperature range of 20 to $40{ }^{\circ} \mathrm{C}$ with no strict column oven control and small variations in flow and organic solvent proportion do not strongly affect the results.

For dissolution medium solutions (Table 6), changes in the medium molarity showed greater influence (p-value closer to 0.05 ) than variations in medium $\mathrm{pH}$. Furthermore, the solutions can be analyzed regardless of endcapped $(\mathrm{C} 8 \mathrm{e})$ or not $(\mathrm{C} 8)$ columns.

A short-term stability data for SIM RS methanolic solution evaluated after $20 \mathrm{~h}$ at $22-24^{\circ} \mathrm{C}$ showed a maximum variation of $0.55 \%$. SIM dissolution medium solution kept at $22-24{ }^{\circ} \mathrm{C}$ showed variations equal to or greater than $2.0 \%$ after $3 \mathrm{~h}(2.0 \%)$ to $7 \mathrm{~h}(3.4 \%)$ standing in room controlled temperature. On the other hand, the maximum variation was $1.1 \%$ after $7 \mathrm{~h}$ under refrigeration $\left(2-8{ }^{\circ} \mathrm{C}\right) .{ }^{34}$ This 
Table 3. HPLC results ${ }^{\mathrm{a}}$ of precision and accuracy $(\% \mathrm{R})$ for SIM tablets in methanol

\begin{tabular}{|c|c|c|c|c|c|c|}
\hline \multirow{3}{*}{ Conc. } & \multicolumn{6}{|c|}{ SIM, $\mu \mathrm{g} \mathrm{mL} \mathrm{mL}^{-1}$ mean (\%RSD) } \\
\hline & \multicolumn{3}{|l|}{ Precision } & \multicolumn{3}{|c|}{ Accuracy } \\
\hline & $\begin{array}{l}\text { Day } 1 \\
(\mathrm{n}=3)\end{array}$ & Day 2 & Day 3 & $\begin{array}{l}\text { Interday } \\
\qquad(n=9)\end{array}$ & $(n=3)$ & $\% \mathrm{R}$ \\
\hline 20 & $19.56(1.20)^{\mathrm{b}}$ & $19.76(1.65)^{\mathrm{b}}$ & $20.25(1.45)^{\mathrm{c}}$ & $19.86(2.02)$ & $20.10(0.99)$ & 100.5 \\
\hline 40 & $39.63(1.86)^{\mathrm{b}}$ & $38.77(1.24)^{\mathrm{b}}$ & $38.55(1.47)^{\mathrm{c}}$ & $38.98(1.84)$ & $39.79(0.94)$ & 99.5 \\
\hline 80 & $78.01(0.76)^{\mathrm{b}}$ & $77.79(0.08)^{\mathrm{b}}$ & $77.00(1.70)^{\mathrm{c}}$ & $77.60(1.10)$ & $79.63(1.30)$ & 99.5 \\
\hline
\end{tabular}

a: conditions as in Table 1; b: analyst I; c: analyst II.

Table 4. HPLC results ${ }^{\mathrm{a}}$ of precision and accuracy (\% R) for SIM tablets in dissolution medium $\left(900 \mathrm{~mL}, 37^{\circ} \mathrm{C}\right.$, paddles, $\left.50 \mathrm{rpm}, 30 \mathrm{~min}\right)$

\begin{tabular}{ccccc}
\hline \multicolumn{5}{c}{ SIM, $\mu$ g mL $\mathrm{m}^{-1}$ mean $(\% \mathrm{RSD})$} \\
Precision \\
\hline Day 1 & Day 2 & Interday & Accuracy & \% R \\
\hline \multicolumn{2}{c}{$(\mathrm{n}=6)$} & $(\mathrm{n}=12)$ & $(\mathrm{n}=3)$ & \\
$21.82(1.50)^{\mathrm{b}}$ & $21.68(1.43)^{\mathrm{b}}$ & $21.75(1.44)^{\mathrm{b}}$ & $2.20(1.75)$ & 99.1 \\
$21.51(1.50)^{\mathrm{c}}$ & $21.76(1.32)^{\mathrm{c}}$ & $21.63(1.47)^{\mathrm{c}}$ & $22.07(1.12)$ & 99.3 \\
& & $21.69(1.45)^{\mathrm{d}}$ & $33.45(2.13)$ & 100.4 \\
\hline
\end{tabular}

a: HPLC conditions and dissolution medium as in Table 1 and Table 2, respectively; b: analyst I; c: analyst II; d: average, $\mathrm{n}=24$.

Table 5. HPLC results of robustness for SIM tablets in methanol

\begin{tabular}{lccc}
\hline $\begin{array}{l}\text { SIM Robustness }(\mathrm{n}=6) \\
\text { Parameters }\end{array}$ & Mean $\mu \mathrm{gL}^{-1}(\%)$ & \%RSD & $p$ \\
\hline $\begin{array}{l}\text { Methanol ratio (\%) } \\
78\end{array}$ & $38.80(97.00)$ & 0.37 & 0.47 \\
$80^{\text {a }}$ & $38.91(97.28)$ & 0.48 & \\
82 & $38.82(97.04)$ & 0.45 & \\
Flow rate $\left(\mathrm{mL} \mathrm{min}^{-1}\right)$ & & & \\
1.4 & $38.98(97.44)$ & 0.42 & 0.74 \\
$1.5^{\text {a }}$ & $38.91(97.28)$ & 0.48 & \\
1.6 & $38.98(97.46)$ & 0.45 & \\
Temperature $\left({ }^{\circ} \mathrm{C}\right)$ & & & \\
20 & $38.86(97.15)$ & 0.56 & 0.73 \\
$30^{\text {a }}$ & $38.91(97.28)$ & 0.48 & \\
40 & $38.96(97.39)$ & 0.52 & \\
\hline
\end{tabular}

a: standardized (nominal) HPLC conditions C8 $(250 \times 4 \mathrm{~mm}, 5 \mu \mathrm{m}), 30{ }^{\circ} \mathrm{C}$, methanol:0.1\% phosphoric acid (80:20 v/v), $1.5 \mathrm{~mL} \mathrm{~min}^{-1}$, UV/DAD $\lambda 238 \mathrm{~nm}$, $10 \mu \mathrm{L}$.

fact can be explained by SIM temperature sensitiveness. ${ }^{40}$ These results indicate that SIM can be assayed under room temperature in methanolic solutions, as well as, for dissolution test. However, it is recommended that SIM solutions to be kept under refrigeration for release profile studies, which are, usually, longer tests.

Because the release profile is an important stage in the development and quality monitoring of the pharmaceutical products, $\mathrm{C} 8 \mathrm{e}$ (As $1.00, \%$ RSD 0.12) was preferred rather than a C8, (As 1.20, \% RSD 0.32 ), since more symmetric peaks were obtained. ${ }^{31}$ In addition, a HPLC method was chosen for SIM tablets dissolution studies due to improved analytical sensitivity and reduced interference from excipients, without any sample treatment. Contrastingly, a method using UV spectrophotometric is described in international compendia for SIM tablets monograph, in which a sample preparation (centrifugation
Table 6. HPLC results of robustness for SIM tablets in methanol and in dissolution medium

\begin{tabular}{|c|c|c|c|}
\hline \multicolumn{4}{|l|}{ SIM Robustness ( $\mathrm{n}=6$ ) } \\
\hline Parameters & Mean $\mu \mathrm{g} \mathrm{mL}^{-1}(\%)$ & $\%$ RSD & $p$ \\
\hline \multicolumn{4}{|l|}{$\mathrm{pH}$} \\
\hline $6.5^{\mathrm{a}}$ & $21.78(98.00)$ & 1.46 & 0.86 \\
\hline $7.0^{\mathrm{a}, \mathrm{b}}$ & $21.82(98.20)$ & 0.93 & \\
\hline $7.5^{\mathrm{a}}$ & $21.85(98.33)$ & 1.35 & \\
\hline \multicolumn{4}{|l|}{ Medium molarity } \\
\hline $0.005^{\mathrm{a}}$ & $21.72(97.75)$ & 1.05 & 0.14 \\
\hline $0.010^{\mathrm{a}, \mathrm{b}}$ & $21.82(98.20)$ & 0.93 & \\
\hline $0.015^{\mathrm{a}}$ & $21.51(96.78)$ & 1.55 & \\
\hline \multicolumn{4}{|l|}{ C8 column } \\
\hline endcapped ${ }^{\mathrm{b}}$ & $21.56(97.04)$ & 1.31 & 0.10 \\
\hline non-endcapped ${ }^{\mathrm{a}, \mathrm{b}}$ & $21.82(98.20)$ & 0.93 & \\
\hline
\end{tabular}

a: standardized (nominal) HPLC conditions as in Table 5; b: dissolution test nominal conditions: $0.5 \%$ SDS in monobasic sodium phosphate $(\mathrm{pH} 7,0.01$ M), $900 \mathrm{~mL}, 37^{\circ} \mathrm{C}$, paddles, $50 \mathrm{rpm}, 30 \mathrm{~min}$.

with pre-washed manganese dioxide) is required after SIM dissolution test, before drug quantitation..$^{2,29}$

Zocor $^{\circledR}$ rapidly dissolving tablets release profile (Figure 7) was greater than $85 \%$ in 10 min. The RSD precision values between days for time points above $85 \%$ drug release $(10,12,15,30,45 \mathrm{~min})$ and below ( $8 \mathrm{~min}$ ) were less than 5 and $10 \%$, respectively. ${ }^{32}$ Time points 3 and 5 min were not considered because of high RSD values (>20\%) found for six units tested each day. These results attest that proposed method is adequate for SIM tablets in vitro release studies.

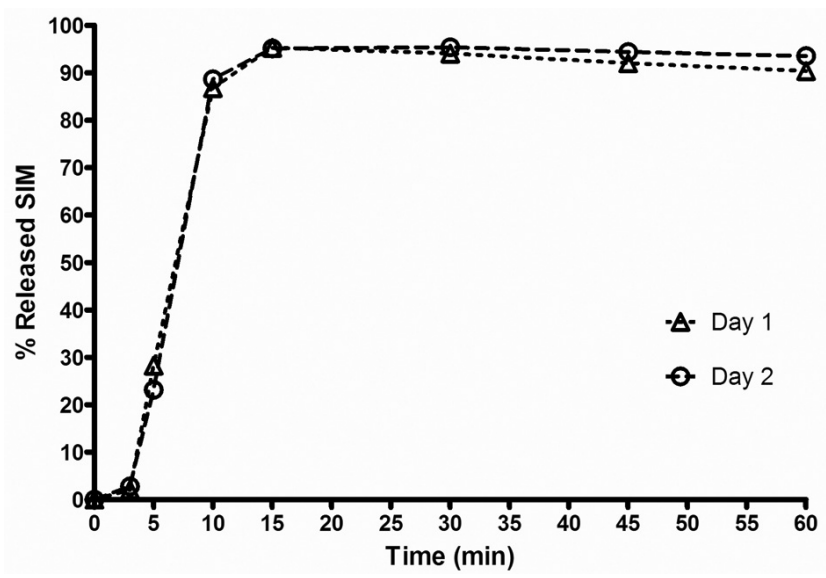

Figure 7. SIM $20 \mathrm{mg}$ tablets $(n=6)$ release profiles in different days $(n=2)$. Conditions: $0.5 \%$ SDS in monobasic sodium phosphate ( $p H 7,0.01 \mathrm{M})$, $900 \mathrm{~mL}, 37^{\circ} \mathrm{C}$, paddles, $50 \mathrm{rpm}$ for $45 \mathrm{~min}, 150 \mathrm{rpm}$ for $15 \mathrm{~min}$ 
In summary, the proposed RP-HPLC method advantages are the lower cost (50\% less than ACN) and the absence of sample treatment after dissolution test compared to the UV method. ${ }^{2,29}$ In addition, it presented a low total run time $(7.4 \mathrm{~min})$ in isocratic elution, high selectivity towards SIM and LOV (SIM synthesis route precursor) degradation products in a wide concentration range $(0.04-0.80 \mu \mathrm{g}$ equivalent to $4-80 \mu \mathrm{g} \mathrm{mL}^{-1}$ ), with similar backpressure regarding ACN use (125 versus 130 bar). Furthermore, a liquid chromatographic method had not yet been applied to SIM tablets using official dissolution test conditions. ${ }^{2,29}$

\section{CONCLUSION}

An alternative validated method using RP-HPLC was successfully applied for SIM assay, as well as, for dissolution test and profile studies in tablets. The method demonstrated to be fast, simple, feasible and affordable when challenged for robustness either in assay conditions, especially for temperature, or in dissolution conditions, after buffer molarity and $\mathrm{pH}$ variations.

\section{ACKNOWLEDGMENTS}

The authors acknowledge Fapemig and CAPES for funding sources.

\section{REFERENCES}

1. O’Neil, M. J.; Heckelman, P. E.; Koch, C. B.; Roman, K. J.; Kenny, C. M.; D’Arecca, M. R.; The Merck index: an encyclopedia of chemicals, drugs and biological, $14^{\text {th }}$ ed.; Merck \& Company: Whitehouse Station: NJ, 2006.

2. The United States Pharmacopeia, $34^{\text {th }}$ ed., United States Pharmacopeial Convention: Rockville, 2011.

3. Scandinavian Simvastatin Survival Study Group; Lancet 1994, $344,1383$.

4. Moghadasian, M. H.; Life Sci. 1999, 65, 1329.

5. Endo, A.; Kuroda, M.; Tisujita, Y.; J. Antibiot. 1976, 29, 1346.

6. Endo, A.; J. Lipid Res. 1992, 33, 1569.

7. Hirama, M.; Iwashita, M.; Tetrahedron Lett. 1983, 24, 1811.

8. Alberts, A. W.; Chen, J.; Kuron, G.; Hunt, V.; Huff, J.; Hoffman, C.; Rothrock, J.; Lopez, M.; Joshua, H.; Harris, E.; Patchett, A.; Monaghan, R.; Currie, S.; Stapley, E.; Albers-Schonberg, G.; Hensens, O.; Hirshfield, J.; Hoogsteen, K.; Liesch, J.; Springer, J.; Proc. Natl. Acad. Sci. U.S.A. 1980, 77, 3957.

9. Hoffman, W. F.; Alberts, A. W.; Anderson, P. S.; Chen, J. S.; Smith, R. L.; Willard, A. K.; J. Med. Chem. 1986, 29, 849.

10. Arayne, M. S.; Sultana, N.; Hussain, F.; Ali, S. A. F.; J. Anal. Chem. 2007, 62, 536 .

11. Wang, L.; Asgharnejad, M.; J. Pharm. Biomed. Anal. 2002, 21, 1243.

12. Gomes, F. P.; García, P. L.; Alves, J. M. P.; Singh, A. K.; Kedor-Hackmann, E. R. M.; Santoro, M I. R. M.; Lat. Am. J. Pharm. 2009, 28, 261.

13. Polonini, H. C.; Santos, F. C.; Vaz, P. U.; Brandão, M. A. F.; Quim. Nova 2011, 34, 516

14. Pasha, Md. K.; Muzeeb, S.; Basha, S. J. S.; Shashikumar, D.; Mullangi, R.; Srinivas, N. R.; Biomed. Chromatogr. 2005, 20, 282.
15. Abu-Nameh, E. S. M.; Shawabkeh, R. A.; Ali, A.; J. Anal. Chem. 2006, $61,63$.

16. Godoy, R.; Godoy, C. G.; Diego, M.; Gómez, C.; J. Chil. Chem. Soc. 2004, 49, 289.

17. Grahek, R.; Milivojevic, D.; Bastarda, A.; Kracun, M.; J. Chromatogr., A 2001, 918, 319.

18. Markman, B. E. O.; Rosa, P. C. P.; Koschtschak, M. R. W.; Rev. Saúde Publ. 2010, 44, 1055.

20. Basavaiah, K.; Tharpa, K.; Chem. Ind. Chem. Eng. Q 2008, 14, 205.

21. Madan, J.; Thakkar, V.; Dwivedi, A. K.; Singh, S.; J. Scient. Ind. Res. 2007, 66, 371.

22. Vuletic, M.; Cindric, M.; Koruznjak, J. D.; J. Pharm. Biomed. Anal. $\mathbf{2 0 0 5}, 37,715$.

23. Oliveira, M. A.; Yoshida, M. I.; Gomes, E. C. L.; Mussel, W. N.; ViannaSoares, C. D.; Pianetti, G. A.; Quim. Nova 2010, 33, 1653.

24. Palabiyik, I. M.; Onur, F.; Yardimci, C.; Özaltin, N.; Quim. Nova 2008, $31,1121$.

25. Hefnawy, M.; Al-Omar, M.; Julkhuf, S.; J. Pharm. Biomed. Anal. 2009, $50,527$.

26. Ashfaq, M.; Khan, I. U.; Asghar, M. N.; J. Chil. Chem. Soc. 2008, 53, 1617.

27. Kumar, V.; Shah, R. P.; Singh, S.; J. Pharm. Biomed. Anal. 2008, 47, 508.

28. Srinivasu, M. K.; Raju, A. N.; Reddy, G. Om.; J. Pharm. Biomed. Anal. 2002, 29, 715 .

29. British Pharmacopoeia, The Stationery Office: London, vol. 3, 2011.

30. http://chromatographyonline.findanalytichem.com/lcgc/article/ articleDetail.jsp $? \mathrm{id}=605650 \&$ sk $=\&$ date $=\&$ page $\mathrm{ID}=4$, accessed February 2012.

31. Snyder, L. R.; Kirkland, J. J.; Glajch, J. L.; Practical HPLC Method Development, $2^{\text {nd }}$ ed., John Wiley: New York, 1997.

32. The United States Pharmacopeia, $34^{\text {th }}$ ed., The dissolution procedure: development and validation <1092> United States Pharmacopeial Convention: Rockville, 2011.

33. Souza, S. V. C.; Junqueira, R. G.; Anal. Chim. Acta 2005, 552, 25

34. Shabir, G. A.; J. Chromatogr., A 2003, 987, 57.

35. Ermer, J.; J. Pharm. Biomed. Anal. 2001, 24, 755.

36. Ribeiro, R. L. V.; Bottoli, C. B. G.; Collins, K. E.; Collins, C. H.; J. Braz. Chem. Soc. 2004, 15, 300.

37. Lanças, F. M.; Sci. Chromatogr. 2009, 1, 51.

38. Ochiai, H.; Uchiyama, N.; Imagaki, K.; Hata, S.; Kamei, T.; J. Chromatogr., B: Anal. Technol. Biomed Life Sci. 1997, 694, 211.

39. Yang, D. J.; Hwang, L. S.; J. Chromatogr., A 2006, 1119, 277.

40. Piecha, M.; Sarakha, M.; Trebse, P.; Kocar, D.; Environ. Chem. Lett. 2010, 8, 185.

41. Alvarez-Lueje, A.; Valenzuela, C.; Squella, J. A.; Núnez-Vergara, L. J.; J. AOAC Int. 2005, 88, 1631.

42. Rozet, E.; Ceccato, A.; Hubert, C.; Ziemons, E.; Oprean, R.; Rudaz, S.; Boulanger, B.; Hubert, P.; J. Chromatogr., A 2007, 1158, 111.

43. Horwitz, W.; Pure Appl. Chem. 1995, 67, 331.

44. Jenke, D. R.; J. Liq. Chromatogr. Relat. Technol. 1996, 19, 737. 